\title{
THE SERUM CONCENTRATION OF HBSAG IN PATIETS WITH CHB/HIV CO-INFECTION COMPARING WITH CHB MONO-INFECTION IN THE DIFFERENT PHASES OF NATURAL COURSE OF CHRONIC HEPATITIS B
}

\author{
Larisa Moroz \\ Department of Infectious Diseases with Epidemiology course \\ Vinnitsa National Pirogov Memorial Medical University \\ 56 Pirogov str., Vinnitsa, Ukraine, 21018 \\ larisa652002@yahoo.com \\ Tetiana Melnyk \\ Department of Infectious Diseases with Epidemiology course \\ Vinnitsa National Pirogov Memorial Medical University \\ 56 Pirogov str., Vinnitsa, Ukraine, 21018 \\ k_tetyana@mail.ru
}

\begin{abstract}
The prevalence and inclination to chronization of viral hepatitis B is 3-5 times higher in patients with HIV-infection than in HIV-negative ones. The natural clinical course of chronic hepatitis B (CHB) in patients with HIV has the features, connected with immune suppression and mutual influence of viruses. The quantitative determination of HBsAg allows the more precise monitoring of the natural course and the dynamics of treatment of patients with CHB but these features are little studied in patients with co-infection $\mathrm{CHB} / \mathrm{HIV}$.

In the work was presented the comparative analysis of the results of quantitative determination of the serum $\mathrm{HBsAg}$ in $59 \mathrm{~Pa}-$ tients with co-infection $\mathrm{CHB} / \mathrm{HIV}$ and 60 ones with chronic hepatitis. At the study it was established, that in patients with $\mathrm{CHB} / \mathrm{HIV}$ co-infection were observed the reliably higher qHBsAg levels than in HIV-negative ones both in whole and in each CHB phase that depends on the immune suppression degree and DNA level of hepatitis B virus.

Keywords: hepatitis B virus (HBV), chronic hepatitis B (CHB), quantitative determination of HBsAg, (qHBsAg), HBV-DNA of hepatitis B virus, HIV-infection, CD4+ quantity.
\end{abstract}

\section{Introduction}

The prevalence of chronic hepatitis B in the world is 350-400 million persons (according to WHO data, 1,49 for 100000 population). At the same time the prevalence in different countries is from $0,2 \%$ to $20 \%$ [1]. By CHB level, Ukraine relates to the moderately precinctive regions (the level of infection of population is 2-7\%) [1]. According to the estimated data, the number of hepatitis B virus carriers in Ukraine exceeds 1 mln persons (mass screening was not realized).

HBV prevalence in the different groups of HIV-infected of European region, according to WHO data, among the injective drugs users (IDU) is 7-10\%, among men that have sex with men (MSM) - 9-17\%, among persons, infected with CHB/HIV by heterosexual way $-4-6 \%$ [2].

The risk of chronization of acute HBV in HIV-negative persons is 5-10\%, whereas in HIV-positive ones and in patients with other types of immune suppression the risk is 3-5 times higher [3]. The qualitative determination of HBsAg is used for the screening of patients for revelation of $\mathrm{HBV}$ infection. In further at the positive result it is recommended to undergo the series of serological (HBeAg, HBeIg, HBcorIg, HBsAgIg) and molecular-genetic (HBV-DNA) tests. The typical course of chronic hepatitis B is characterized with the presence of HBsAg, HBcor Ig total, presence or absence of HBeAg and different HBV-DNA level. Seroconversion is determined correspondingly at appearance of antibodies (Ig) to HBeAg and HBsAg in the blood, absence of antigens and HBV-DNA.

The natural course of chronic hepatitis B is presented by three successive phases of disease: immunotolerant, phase of immune clearance (immunoactive) - replicative, phase of im- 
mune control (inactive carriage) - low-replicative/non-replicative. The fourth phase of reactivation (HBeAg-negative CHB) - replicative is also separated [4-7].

- immune tolerant phase (IT) is typical for the perinatal infection and can continue for several decades of life, is attended by the high viremia and presence of $\mathrm{HBeAg}$;

- the phase of immune clearance (IC) is attended by the presence of $\mathrm{HBeAg}$, relatively low level of virus, increase or fluctuation of aminotransferase level;

- low-replicative phase (LR) - inactive carriage can be observed after seroconversion of HBeAg and the presence of antibodies to HBeAg. The very low HBV-DNA level is also typical, sometimes even lower than the level of determination, normal level of amin transferases in the blood serum;

- the phase of reactivation (RA) - HBeAg-negative CHB can develop after seroconversion of HBeAg (appearance of HBeIg) in immune active phase or after several years of carriage of inactive virus. Reactivation of HBV infection with development of HBeAg-negative CHB and sometimes with reversion of $\mathrm{HBeAg}$ and development of $\mathrm{HBeAg}$-positive $\mathrm{CHB}$ is often observed in persons with immune suppression including HIV-infected ones [9]. This stage is in fact the late immune active phase in the natural development of CHB. It is characterized with fluctuation of HBV-DNA level and aminotransferases, presence of HBeIg, HBcor Ig, absence of HBsAg Ig [7] (Table 1).

Table 1

The phases of development of chronic hepatitis B [13, 14]

\begin{tabular}{|c|c|c|c|c|c|}
\hline Phase & HBeAganti-HBe & HBsAg & HBV-DNA level & ALT level & Level of histological changes in liver \\
\hline "IT" & $\begin{array}{l}\text { HBeAg “+” } \\
\text { anti-HBe “-”" }\end{array}$ & “+” & $\begin{array}{l}>1 \times 10^{6} \mathrm{IU} / \mathrm{ml}[13] \\
>2 \times 105 \mathrm{IU} / \mathrm{ml}[14]\end{array}$ & norm & Minimal inflammation and fibrosis \\
\hline "IC" & $\begin{array}{c}\text { HBeAg “+”" } \\
\text { anti-HBe “+”" }\end{array}$ & "++" & $\begin{array}{l}>2 \times 10^{4} \mathrm{IU} / \mathrm{ml}[13] \\
>2 \times 10^{3} \mathrm{IU} / \mathrm{ml}[14]\end{array}$ & increased & Inflammation and fibrosis of middle and hard degree \\
\hline “NR" & $\begin{array}{l}\text { HBeAg “-”" } \\
\text { anti-HBe “+”" }\end{array}$ & “+” & $\begin{array}{c}<2 \times 10^{3} \mathrm{IU} / \mathrm{ml} \\
{[13,14]}\end{array}$ & norm & Minimal activity of inflammation and variable fibrosis \\
\hline "RA" & $\begin{array}{c}\text { HBeAg “-”" } \\
\text { anti-HBe "+”" }\end{array}$ & “+” & $\begin{array}{l}>2 \times 10^{3} \mathrm{UI} / \mathrm{ml}[13] \\
>2 \times 10^{4} \mathrm{UI} / \mathrm{ml}[14]\end{array}$ & increased & Inflammation and fibrosis of middle and hard degree \\
\hline
\end{tabular}

There are studies that state that in HBV carriers HBsAg level in the blood serum was $<1000 \mathrm{IU} / \mathrm{ml}[8]$.

Thus serological markers, HBV-DNA level, the levels of transaminases and histological changes in the liver are often used for determination of phase of CHB natural course. But last years the active role is given to the quantitative determination of HBsAg for differentiation of phases of CHB natural course [10-12, 19-21]. According to the literary data, the reliable difference in HBsAg levels is observed in patients with CHB mono-infection. qHBsAg is also used for the prognosis of CHB reactivation. But this question is insufficiently studied for the specific population of patients, namely the ones with HIV/CHB co-infection and the factors that influence qHBsAg in co-infected patients are not sufficiently studied too.

\section{Aim of research}

To study the changes of HBsAg concentration at the different phases of CHB natural course in HIV-infected patients. To determine the factors that influence qHBsAg.

\section{Materials and methods}

59 patients with HIV/CHB co-infection (main group) and 60 patients with CHB monoinfection (control group) were under observation. The main group included 21 women $(35,6 \%)$ and 38 men $(64,5 \%)$ - mean ageт 35,6 $\pm 1,1$ years. The control group included 25 women $(41,7 \%)$ and 35 men $(58,3 \%)$ - mean age $33,9 \pm 1,6$ years. 
All patients were under ambulatory observation in Vinnitsa city hepatological center of City clinical hospital № 1 and MI "Vinnitsa regional center of prophylaxis and fight against AIDS" in 2013-2016.

For distinction of phases of CHB natural course was used determination of HBV markers (HBeAg, HBe Ig, HBcor Ig, HBsAg Ig), HBV-DNA, alanine aminotransferase (ALT) level, APRI non-invasive method of determination of fibrosis degree and also quantitative determination of HBsAg. All observed patients did not receive anti-viral therapy.

Statistical processing of the received results was carried out using the program package “STATUSTICA 5,5”, license № AXXR910A374605FA.“””

\section{Experimental procedures}

The laboratory studies included: determination of HBV serological markers, quantitative determination of HBsAg (IU/ml), quantitative determination of HBV-DNA (IU/ml), level of alanine aminotransferase (ALT) $(\mathrm{Un} / 1)$, level of CD4+ (cells/ $\mu \mathrm{l})$. Serological markers were determined by the method of immune-enzyme analysis (IEA) using spectrophotometer "Sanrise RC". Quantitative determination of HBsAg in the blood serum was carried out by the method of immunocheminuminescence using test-system "HBsAg Architect Kit (6C36)" by "Abbott Laboratories" using automatic analyzer "Architect" (sensitivity - 0,05 IU/ml). Determination of HBV-DNA was carried out by PCR using test-systems "AmpliSense ${ }^{\circledR}$ HBV-FL" using PCR system in the real time Bio-Rad iQ-5 (sensitivity - $50 \mathrm{IU} / \mathrm{ml}$ ). Determination of ALT activity was carried out by kinetic method using automatic biochemical analyzer Vitalab Flexor (referential value - up to $41 \mathrm{Un} / 1$ ). CD4+ level was determined by the method of running cytometry using the running cytometer EPICS-XL (diapason of determination from 1 cells/ $\mu 1$ and more, size of cells $1-40 \mathrm{mcm}$ ).

\section{Results}

The most patients with CHB mono-infection (control group) were in age diapasons 20-29 and 30-39 years that is $76,6 \%$ of patients of the group. At the same time the age diapasons of most patients with co-infection CHB/HIV are a bit displaced to 30-39 and 40-49 years - together 67,8\% of patients of the group (Fig. 1).

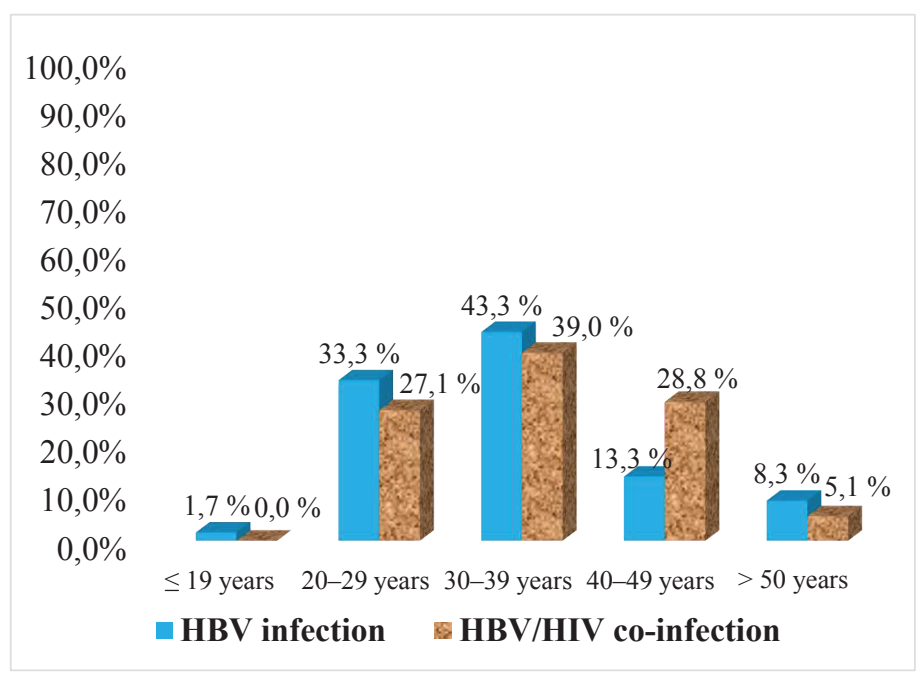

Fig. 1. Distribution of patients with CHB-mono-infection $(n=60) \mathrm{CHB} / \mathrm{HIV}$ co-infection $(n=59)$ in age groups

For comparing the levels of HBsAg serum concentrations in patients in the different phases of natural course, patients were divided in 3 subgroups, according to aforesaid criteria. The phase of "immune clearance" - 6 patients (3 - main, 3 - control), phase of "HBeAg-negative reactivation" - 42 patients (17 - main, 25 - control), "low-replicative phase" - 71 patient (39 - main, 32 - control). The immunotolerant phase was not present in any studied group (Table 2). 
Table 2

qHBsAg $(\mathrm{IU} / \mathrm{ml}) /\left(\log _{10} \mathrm{IU} / \mathrm{ml}\right)$ levels in the blood serum of patients with $\mathrm{CHB} / \mathrm{HIV}$ co-infection depending on CHB phase

\begin{tabular}{|c|c|c|c|}
\hline \multirow{2}{*}{ Phase of disease } & CHB/HIV(main) n=59 & CHB (control) $n=60$ & $\mathbf{p}$ \\
\hline & \multicolumn{3}{|c|}{ HBsAg, IU/ml/( $\left.\log _{10} I U / m l\right)$} \\
\hline $\begin{array}{c}\text { Phase of immune } \\
\text { clearance (IC) - "HBeAg+", } n=6\end{array}$ & $\begin{array}{c}(n=3) * 55195,9 \pm 28861,3 \\
(4,74 \pm 4,46)\end{array}$ & $\begin{aligned}(n=3) & * 40970,4 \pm 23688,3 \\
& (4,61 \pm 4,37)\end{aligned}$ & $\mathrm{p}=0,55$ \\
\hline $\begin{array}{c}\text { Phase of } \\
\text { reactivation (RA) - "HBeAg-", } n=42\end{array}$ & $\begin{array}{c}(\mathrm{n}=17)^{*} 26375,2 \pm 7328,7 \\
(4,42 \pm 3,86)\end{array}$ & $\begin{array}{c}(\mathrm{n}=25)^{*} 11222,0 \pm 2046,3 \\
(4,05 \pm 3,31)\end{array}$ & $\mathrm{p}<0,001$ \\
\hline Low-replicative phase (LR), $\mathrm{n}=71$ & $\begin{array}{c}(\mathrm{n}=39)^{*} 4401,8 \pm 1062,0 \\
(3,64 \pm 3,03)\end{array}$ & $\begin{array}{c}(\mathrm{n}=32)^{*} 2631,2 \pm 615,6 \\
(3,42 \pm 2,79)\end{array}$ & $\mathrm{p}<0,001$ \\
\hline
\end{tabular}

Note: ${ }^{*}-p<0,05$ - between IC, RA and LR phases within the main and control groups; $p<0,05$ - reliable difference between the groups of comparison

Thus the received results testify to the reliable differences of HBsAg serum concentrations level between patients with CHB/HIV co-infection and CHV-infection ( $p<0,001)$, except patients with $\mathrm{HBeAg}$-positive hepatitis in the phase of immune clearance where the difference was not reliable, $\mathrm{p}=0,55$.

At comparison of the phases of chronic hepatitis B course the received values of qHBsAg $\mathrm{IU} / \mathrm{ml}$ ) results were also converted in $\log 10 \mathrm{IU} / \mathrm{ml}$ for more effectiveness. As a result of comparison it was discovered that in the group of $\mathrm{CHB} / \mathrm{HIV}$ co-infected persons HBsAg serum concentration was higher in IC phase comparing with RA by $0,32 \log 10 \mathrm{IU} / \mathrm{ml}$, in RA phase comparing with LR by $0,78 \log 10 \mathrm{IU} / \mathrm{ml}$ and also in IC phase comparing with LR by $1,1 \log 10 \mathrm{IU} / \mathrm{ml}$. The same situation is also in the group of CHB-infected patients: qHBsAg is higher in IC phase comparing with RA by $0,56 \log 10 \mathrm{IU} / \mathrm{ml}$, in RA phase comparing with LR by $0,63 \log 10 \mathrm{IU} / \mathrm{ml}$ and also in IC phase comparing with LR by $1,19 \log 10 \mathrm{IU} / \mathrm{ml}$. The essential difference of $\mathrm{qHBsAg}$ mean values $(\mathrm{p}<0,05)$ was also received within each group.

For explanation of the received reliable differences between qHBsAg of the main and control group and determination of factors that influence HBsAg concentration in patients with $\mathrm{CHB} / \mathrm{HIV}$ co-infection, the analysis of qHBsAg was carried out depending on CD4+ and HBV-DNA level. For assessment of the influence of CD4+ level on HBsAg serum concentration, $\mathrm{CHB} / \mathrm{HIV}$ co-infected patients were divided in three subgroups with distinctive points CD4+ 350 cells $/ \mu 1$ and 500 cells/ $\mu 1$ (Table 3 ).

Table 3

qHBsAg$(\mathrm{IU} / \mathrm{ml}) /(\log 10 \mathrm{IU} / \mathrm{ml})$ levels in the blood serum of patients with $\mathrm{CHB} / \mathrm{HIV}$ co-infection depending on CD4+ quantity (cells/ $\mu \mathrm{l})$

\begin{tabular}{|c|c|c|c|c|c|}
\hline Phase of disease & CD4 $+<350$ cells $/ \mu \mathrm{l}$ & $\mathbf{p}$ & $\begin{array}{c}\text { CD4+ } \\
350-500 \text { cells } / \mu \mathrm{l} \\
\text { HBsAg, IU } / \mathrm{ml} /\left(\log _{10} \mathrm{I}\right.\end{array}$ & nl) & CD4 $+>500$ cells $/ \mu \mathrm{l}$ \\
\hline $\begin{array}{l}\text { Phase of immune clearance (IC), } \\
\text { "HBeAg+", n=3 }\end{array}$ & - & - & - & - & $\begin{array}{c}(\mathrm{n}=3) 55195,9 \pm 28861,3 \\
(4,74 \pm 4,46)\end{array}$ \\
\hline $\begin{array}{c}\text { Phase of reactivation (RA), } \\
\text { "HBeAg-", } n=17\end{array}$ & $\begin{array}{c}(\mathrm{n}=9) \\
47842,9 \pm 20945,3 \\
(4,67 \pm 4,32)\end{array}$ & $\mathrm{p}<0,05$ & $\begin{array}{c}(\mathrm{n}=3) 17697,9 \pm 4152,7 \\
(4,24 \pm 3,62)\end{array}$ & $\mathrm{p}=0,9$ & $\begin{array}{c}(\mathrm{n}=5) 17341,1 \pm 5853,2 \\
(4,23 \pm 3,77)\end{array}$ \\
\hline Low-replicative phase (LR), $n=39$ & $\begin{array}{c}(\mathrm{n}=11) \\
6773,3 \pm 2866,2 \\
(3,83 \pm 3,46)\end{array}$ & $\mathrm{p}<0,05$ & $\begin{array}{c}(\mathrm{n}=13) 4190,7 \pm 1315,9 \\
(3,62 \pm 3,12)\end{array}$ & $\mathrm{p}<0,05$ & $\begin{array}{c}(\mathrm{n}=15) 2845,7 \pm 1378,4 \\
(3,45 \pm 3,14)\end{array}$ \\
\hline
\end{tabular}

Note: $p<0,05$ - reliable difference between the groups of comparison 
The analysis of qHBsAg in patients in IC phase was not carried out because of the presence of patients only in subgroup with CD4+ level $>500$ cells/ $\mu 1$. The received results testify to the influence of CD4+ level on HBsAg serum concentrations, especially at significant immune suppression $(\mathrm{CD} 4+<350$ cells $/ \mu \mathrm{l})$. At analysis of patients in the phase of reactivation it was revealed, that in patients with CD4+<350 cells/ $\mu 1 \mathrm{qHBsAg}$ was by $0,44 \log 10 \mathrm{IU} / \mathrm{ml}$ more than with CD4+ level $>500$ cells $/ \mu 1(p<0,05)$. The reliable difference $(p=0,9)$ is absent between subgroups of patients with CD4+350-500 cells/ $\mu 1$ and $>500$ cells/ $\mu 1$ of RA phase. Among patients of low-replicative phase was traced the reliable difference by $0,38 \log 10 \mathrm{IU} / \mathrm{ml}$ between the extreme CD4+ subgroups of patients $(\mathrm{p}<0,05)$.

HBV-DNA parameter $2 \times 10^{3} \mathrm{IU} / \mathrm{ml}$ was chosen for distinction of subgroups of patients because just this parameter is applied as one of the factors of determination of phases of chronic hepatitis B course [13, 14] (Table 4).

Table 4

qHBsAg(IU/ml $) /\left(\log _{10} \mathrm{IU} / \mathrm{ml}\right)$ levels in the blood serum of patients with $\mathrm{CHB} / \mathrm{HIV}$ co-infection depending on HBV-DNA level

\begin{tabular}{|c|c|c|c|}
\hline \multirow{2}{*}{ Phase of disease } & HBV-DNA $<2 \times 10^{3} \mathrm{IU} / \mathrm{ml}$ & $\mathbf{p}$ & HBV-DNA $>2 \times 10^{3} \mathrm{IU} / \mathrm{ml}$ \\
\hline & \multicolumn{3}{|c|}{ HBsAg, IU/ml/( $\left.\log _{10} I U / m l\right)$} \\
\hline Phase of immune clearance (IC) - "HBeAg+", n=3 & - & - & $\begin{array}{c}(\mathrm{n}=3) 55195,9 \pm 28861,3 \\
(4,74 \pm 4,46)\end{array}$ \\
\hline Phase of reactivation (RA) - "HBeAg-", n=17 & $\begin{array}{c}(\mathrm{n}=4) \\
22825,4 \pm 8782,9 \\
(4,36 \pm 3,94)\end{array}$ & $\mathrm{p}<0,05$ & $\begin{array}{c}(\mathrm{n}=13) \\
37912,1 \pm 12513,5 \\
(4,58 \pm 4,10)\end{array}$ \\
\hline Low-replicative phase (LR), $n=39$ & $\begin{array}{c}(n=28) 3068,0 \pm 1204,4 \\
(3,49 \pm 3,09)\end{array}$ & $\mathrm{p}<0,001$ & $\begin{array}{c}(\mathrm{n}=11) 7797,0 \pm 1902,9 \\
(3,90 \pm 3,30)\end{array}$ \\
\hline
\end{tabular}

Having carried out the comparison in subgroups with HBV-DNA level more/less $2 \times 10^{3} \mathrm{IU} / \mathrm{ml}$ was revealed the reliable difference in both phase of reactivation by $0,22 \log 10 \mathrm{IU} / \mathrm{ml}(\mathrm{p}<0,05)$ and in low-replicative phase by $0,49 \log 10 \mathrm{IU} / \mathrm{ml}(\mathrm{p}<0,001)$.

\section{Discussion}

Taking into account the large number of works, devoted to the mutual connection of qHBsAg and the phases of CHB natural course in HIV-negative patients [8, 10-12, 17], in this research was realized the comparative analysis of the results of quantitative determination of HBsAg in HIV-positive and HIV-negative patients in the different phases of CHB natural course. The received qHBsAg results that characterize the "phase of reactivation of HBeAg-negative CHB" and "low-replicative phase" demonstrated the reliably more HBsAg serum concentrations in $\mathrm{CHB} / \mathrm{HIV}$ co-infected patients comparing with ones of the control group $(p<0,001)$. In the phase of "immune clearance" the reliable difference between the main and control group was not observed that was probably limited by the number of patients related to this group $(\mathrm{p}=0,55)$. At the same time in $\mathrm{CHB} / \mathrm{HIV}$ co-infected patients the most HBsAg serum concentration was observed in IC phase and the least one - in LR phase with the difference $1,1 \log 10 \mathrm{IU} / \mathrm{ml}(\mathrm{p}<0,001)$.

The existent studies showed the influence of CD4+ level, presence of HBV-DNA on HBsAg serum concentration $[15,16,18]$.

The received results also testify to the influence of immune suppression (CD4 $+<350$ cells/ $\mu$ l) on the increase of HBsAg serum concentrations in both "phase of reactivation of HBeAg-negative CHB" and "low-replicative phase" $(\mathrm{p}<0,05)$. The lowest HBsAg serum concentration is in persons with CD4+ level $>500$ cells $/ \mu 1(p<0,05)$

After determination of $\mathrm{HBV}$ in the group of patients with $\mathrm{CHB} / \mathrm{HIV}$ co-infection it was also elucidated, that among persons with HBV-DNA level $>2000 \mathrm{IU} / \mathrm{ml}$ the mean index of serum 
HBsAg was reliably higher comparing with patients with HBV-DNA $<2000 \mathrm{IU} / \mathrm{ml}$ in both RA phase $(p<0,05)$ and LR phase $(p<0,001)$. These results are comparable with the literary sources $[15,16]$.

\section{Conclusions}

1. Thus in patients with $\mathrm{CHB} / \mathrm{HIV}$ co-infection is observed the reliably higher qHBsAg levels than in HIV-negative patients in whole and in each separate phase of CHB.

2. The quantities of CD4+, HBV-DNA are the node factors, reliably connected and influencing HBsAg serum concentration in $\mathrm{CHB} / \mathrm{HIV}$ co-infected patients.

3 . Based on the received results it would be expedient the early (CD4+>500 cells $/ \mu \mathrm{l})$ prescription of nucleos inhibitors of reverse transcriptase with double activity that allows receive the effective immune response to the treatment of both HIV-infection and chronic hepatitis B and also avoid the development of syndrome of renewal of immune system and aggravation of the chronic disease of the liver, connected with HBV.

\section{References}

[1] (2011). Management of hepatitis B and HIV coinfection Clinical Protocol for the WHO European Region. WHO, 31. Available at: http://www.euro.who.int/__data/assets/pdf_file/0011/152012/e95792.pdf

[2] Emiroglu, N. (2010). Viral hepatitis burden and policy directions in the European region of WHO: Summit Conference on Hepatitis B and C. 20.

[3] Pol, S. (2013). Management of HBV in immunocompromised patients. Liver International, 33, 182-187. doi: 10.1111/liv.12055

[4] Fattovich, G. (2003). Natural History and Prognosis of Hepatitis B. Seminars in Liver Disease, 23 (1), 047-058. doi: 10.1055/s-2003-37590

[5] McMahon, B. J. (2004). The Natural History of Chronic Hepatitis B Virus Infection. Seminars in Liver Disease, 24, 17-21. doi: 10.1055/s-2004-828674

[6] Lok, A. S. F., McMahon, B. J. (2007). Chronic hepatitis B. Hepatology, 45 (2), 507-539. doi: 10.1002/hep. 21513

[7] EASL Clinical Practice Guidelines: Management of chronic hepatitis B virus infection. (2012). Journal of Hepatology, 57 (1), 167-185. doi: 10.1016/j.jhep.2012.02.010

[8] Brunetto, M. R., Oliveri, F., Colombatto, P., Moriconi, F., Ciccorossi, P., Coco, B. et. al. (2010). Hepatitis B Surface Antigen Serum Levels Help to Distinguish Active From Inactive Hepatitis B Virus Genotype D Carriers. Gastroenterology, 139 (2), 483-490. doi: 10.1053/j.gastro.2010.04.052

[9] Abdurahmanov, D. T. (2008). Kliniko-serologicheskie variantyi hronicheskoy HBV-infektsii. Klinicheskaya, 4 (1), 30-34.

[10] Thompson, A. J. V., Nguyen, T., Iser, D., Ayres, A., Jackson, K., Littlejohn, M. et. al. (2010). Serum hepatitis B surface antigen and hepatitis B e antigen titers: Disease phase influences correlation with viral load and intrahepatic hepatitis B virus markers. Hepatology, 51 (6), 1933-1944. doi: 10.1002/hep.23571

[11] Jaroszewicz, J., Serrano, B. C., Wursthorn, K., Deterding, K., Schlue, J., Raupach, R. et. al. (2010). Hepatitis B surface antigen (HBsAg) levels in the natural history of hepatitis B virus (HBV)-infection: A European perspective. Journal of Hepatology, 52 (4), 514-522. doi: 10.1016/j.jhep.2010.01.014

[12] Chan, H. L.-Y., Wong, V. W.-S., Wong, G. L.-H., Tse, C.-H., Chan, H.-Y., Sung, J. J.-Y. (2010). A longitudinal study on the natural history of serum hepatitis B surface antigen changes in chronic hepatitis B. Hepatology, 52 (4), 1232-1241. doi: 10.1002/hep.23803

[13] Norah, A. T., Bzowej, N. H., Chang, K.-M., Hwang, J. P., Jonas, M. M., Murad, M. H. (2015). Guidelines for Treatment of Chronic Hepatitis B. Practice guideline. Hepatology, 1-23.

[14] Who guidelines for the prevention, care and treatment of persons with chronic hepatitis b infection (2015). WHO guidelines, 1-166. Available at: http://apps.who.int/iris/bitstre am/10665/154590/1/9789241549059_eng.pdf?ua=1\&ua=1

[15] Jaroszewicz, J., Reiberger, T., Meyer-Olson, D., Mauss, S., Vogel, M., Ingiliz, P. et. al. (2012). Hepatitis B Surface Antigen Concentrations in Patients with HIV/HBV Co-Infection. PLoS ONE, 7 (8), e43143. doi: 10.1371/journal.pone.0043143 
[16] Psevdos, J., Jong, H. K., Sharp, V. L. (2010). Predictors of loss hepatitis B surface antigen in HIV-infected patients. World Jornal of Gasroenterology, 16 (9), 1093-1096. doi: 10.3748/wjg.v16.i9.1093

[17] Dudina, K. R., Znojko, O. O., Shut'ko, S. A., Klimova, E. A., Kuzina, L. E., Braginskij, D. M., Blohina, N. P., Jushhuk, N. D. (2011). Dinamicheskoe opredelenie kolichestvennogosoderzhaniya HBsAg $\mathrm{v}$ krovi v sopostavlenii s urovnem virusnoy nagruzki u patsientov s hronicheskoy HBV-monoinfektsiey. Russkiy zhurnal gastroenterologii, gepatologii, koloproktologii, 4, 37-42. Evailable at: http://www.gastro-j.ru/article/366-dinamicheskoe-opredelenie-kolichestvennogo-soderzhaniya-hbsag-v-krovi-v-sopostavlenii-s-urovnem-/show/full/

[18] Puoti, M., Torti, C., Bruno, R., Filice, G., Carosi, G. (2006). Natural history of chronic hepatitis B in co-infected patients. Journal of Hepatology, 44, S65-S70. doi: 10.1016/j.jhep.2005.11.015

[19] Martinot-Peignoux, M., Moucari, R., Leclere, L., Cardoso, A.-C., Carvalho, R., Boyer, N. et. al. (2010). 725 QUANTITATIVE HBSAG: A NEW SPECIFIC MARKER FOR THE DIAGNOSIS OF HBSAG INACTIVE CARRIAGE. Journal of Hepatology, 52, S282. doi: 10.1016/s0168-8278(10)60727-1

[20] Seth, A. K. (2012). HBsAg Quantification in Clinical Practice. Journal of Clinical and Experimental Hepatology, 2 (1), 75-80. doi: 10.1016/s0973-6883(12)60084-x

[21] Çelik, M., Arabul, M., Çekiç, C., Vatansever, S., İpek, S., Aslan, F., Ünsal, B. (2014). Clinical utility of hepatitis B surface antigen levels during the natural history and treatment of chronic hepatitis B infection. Gastroenterology Review, 3, 164-167. doi: 10.5114/pg.2014.43758 